\title{
Montessori Junior High School Students' Perceptions on Their Self-Efficacy in Reading
}

\author{
Niko Albert Setiawan, 181242023@student.usd.ac.id, Sanata Dharma University, \\ Yogyakarta, Indonesia \\ Ouda Teda Ena, ouda@usd.ac.id, Sanata Dharma University, Yogyakarta, Indonesia
}

\begin{abstract}
The Montessori approach deals with learning in independence and liberty. This way of learning requires students to explore information based on their learning interests. Therefore, reading has become one of the keys to learning success in a Montessori school. Moreover, the impact of self-efficacy on the learning outcomes has been explored in educational psychology as a field of study. This study inspects students' self-efficacy perceptions and their factors in reading comprehension in a Montessori Junior High School registered in the 2018-2019 academic year. It is located in Yogyakarta, Indonesia. English is the main language used in the teachinglearning process in the school. The study is conducted using the mixed method. Findings are based on the 27 close-ended questions and three openended questions obtained from the students in grades seven and eight. In analyzing the results, a concurrent triangulation strategy is applied. The results show that the students have positive self-efficacy perceptions on their reading $($ Average $=3.449 / 5)$, especially in reading, explaining, summarizing texts and comprehending the graphics found in the text without the guidance of their teachers. Their self-efficacy sources are found in their mastery experiences, vicarious experiences, verbal persuasion, and emotional and psychological states.
\end{abstract}

Keywords: self-efficacy, Montessori approach, reading

\section{INTRODUCTION}

Mostly, the Montessori approach has been applied in Indonesia in the education of young learners. Though, there are some Montessori Junior High Schools in Indonesia, especially in Yogyakarta. These schools were outnumbered by most of the other schools which apply the classical approach as the base of the teaching-learning process.

The Montessori approach has become a new trend in Indonesia's education. The Montessori approach is defined as the approach which the concept of freedom, independence, and the elimination of prizes and external forms of penalty have become the main concern (Montessori, 2014). It means that a Montessori approach is an approach that emphasizes students' freedom and internal learning motivation in the learning process. This approach makes the students must be able to explore information based on their internal learning motivation since extrinsic rewards and punishments are evaded (A. S. Lillard, 2005). In Montessori students' learning, reading is central.

In achieving the learning goals, moreover, self-efficacy in reading plays a vital role in shaping students' chances for accomplishment. Self-efficacy is defined as an individual's trust in his or her ability to perform actions that are essential to do such precise accomplishments (Bandura, 1977, 1986, 1997). Consequently, students' positive self-efficacy perception of reading is one of the important factors in becoming successful learners in Montessori. In this setting, it is worth to explore Montessori students' self-efficacy perceptions on reading 
comprehension.

Psychology concerns the sound inquiry of what people think and do (Long, 2000). Psychology can be applied in a wide variety of fields, including education. There are still many argumentations related to education. Psychologically, we cannot judge something without any logical investigation and research. Therefore, educational psychology plays a role in finding the truth about what people think and do related to education logically by providing shreds of evidence.

There are a lot of ways to investigate something. Related to modifying the reality or not, it is divided into two, experimental investigations and non-experimental investigations (Long, 2000). Experimental approaches involve the change of something that will be investigated in an object; then, it will be compared to others. On the other hand, non-experimental approaches are based on the observational techniques in the natural research object. Related to the measurement, it is divided into two; quantitative approaches and qualitative approaches. The quantitative approaches make use of the strength of statistical techniques. While the qualitative approaches focus more on the detail information gained in reality rather than in amount. Moreover, triangulation means the use of different types of investigations to compare to conclude (Long, 2000).

'Pure' psychology gives us the theories to more comprehend elementary ranges such as education, recollection, motivation, etc.; while, practical education in the complex real-life situation. Hence, it is vital to assess real applications of psychological philosophies than pure ones (Long, 2000). With the help of a psychological perspective, we can explore the truth well by providing theories and knowledge about the advantages and disadvantages of decision making related to education (Long, 2000).

Educational psychology is a branch of psychology in educational settings. In other words, it involves the understanding of how humans learn and its use to explore the best teaching ways. Some perspectives on learning are identified. The points of view on learning are various. Therefore, it is needed to compare and contrast them to create a better understanding of the perspectives. The perspectives on learning are behaviorism, cognitivism, and constructivism.

Behaviorism involves in terms of changes in behavior caused by experiences (Ireson, 2008). It focuses on the shaping and moulding of observed behavior through the manipulation of consequences and antecedents (e.g., rewards and punishments). The purpose of the learning perspective is to help teachers shape students' appropriate behavior. This perspective is very similar to the social learning theories which involve modelling. In the social learning theories, the learners learn by observing and imitating others. (Ireson, 2008).

Cognitivism emphasizes mental processes such as thinking, reasoning, and problemsolving (Ireson, 2008). It focuses on how the mind receives, organizes, stores, and retrieves information. It is often used in teaching something complicated and difficult.

Constructivism concerns meaningful learning from experience. Marton and Booth said that constructivism has the characteristic related to individuals' experiences of teaching and learning (Ireson, 2008). Ireson (2008) says that "constructivist believed that knowledge is constructed by individuals as they interact with the world around them." Students more interest in learning when they can be connected with the concept and problem. Meaningful contexts support the students to explore information based on their previous involvements. By applying this perspective on learning, teachers can encourage their students more active in the learning process.

There are three differences and similarities from the three perspectives on learning stated before. First, it is related to the things being changed or transformed. Behaviourism focuses on the observed behavior. On the other hand, cognitivism involves mental processes 
such as thinking, reasoning, and problem-solving. However, constructivism focuses on the use of meaningful experiences to gain knowledge. Second, it is related to problem-solving. The three perspectives on learning all focus on problem-solving. Third, both behaviorism and constructivism's learning are from experiences.

Self-efficacy is an individual's trust in his or her capability to do actions that are essential to do such precise accomplishments (Bandura, 1977, 1986, 1997)., it can be said that self-efficacy is someone's confidence to motivate him/herself to do such a thing. Therefore, in the research instruments, self-efficacy is translated into confidence (in Indonesian= kepercayaan diri). Bandura (1977) says that it is one's belief to do something and achieve the desired goal of the action. Similarly, Pintrich (Pintrich, 2003)states that self-efficacy is someone's belief in their capacity to do a task.

Bandura (1994) explains that there are four sources of self-efficacy that can influence someone's self-efficacy, namely mastery experiences, vicarious experiences, verbal persuasion, emotional and psychological states, and imaginable experiences.

\section{Mastery Experiences}

The foremost and the main source of self-efficacy is through direct experience, which is called mastery experiences. Direct experiences do build someone's confidence to accomplish such a goal in the future. For example, people who have done such accomplishment in doing a specific sport must have high self-belief in doing the sport (Bandura, 1997).

2. Vicarious Experiences

People around us can also become the second source of our self-efficacy. Observation of people around us in doing such activities can impact our self-belief. For example, when we see people who do something which we need to do successfully, we can observe them, and they can become role models in doing the same or similar thing (Bandura, 1997).

3. Verbal Persuasion

Bandura (1997) also explains that people around us, such as parents, teachers, managers, or coaches, can strengthen us in achieving our goal. They can persuade us to master certain actions or activities. Through their words, the impact can be felt by us and will directly or indirectly impact our self-efficacy.

4. Emotional and Physiological States

In this source, our emotional and physiological factors can be the stimulus of our selfefficacy (Bandura, 1997). For example, depression and stress can harm our self-efficacy in doing such performance. On the other hand, positive emotions can enhance our confidence in our ability and skills.

5. Imaginable Experiences

Visualizing ourselves that we can do it can also be the key to have a high level of selfefficacy. Imagination sometimes matters in achieving our self-belief in doing such performance (Bandura, 1997). For instance, imagining that we are doing great in our future speech can decrease our depression and anxiousness in our real speech.

In Montessori, there are three planes, stages of development, which has been recognized. The three developmental stages are absorbent mind, from birth to age six; the second plane, from age six to twelve; and the third plane, from age twelve to eighteen. (Montessori, 2004; Lillard, 1996; Lillard, 2005). This research focuses on the third plane of Montessori planes, the adolescent.

Additionally, Lillard (P. P. Lillard, 1996) labels that the Montessori approach emphases the students and their needs remark. She also explains that the achievement of the Montessori approach rests on the three main applications, namely, the prepared learning environment, the prepared teachers and parents, and students' freedom with responsibility. Besides, Lillard (2005) defines the Montessori approach into eight values, namely: 1. Learning by doing, 2 . 
Choice, 3. Interest, 4. Extrinsic Rewards and Punishments are avoided, 5. Learning with and from Peers, 6. Learning in Context, 7. Teacher's Personal Guidance and 8. Order in Environment and Mind

In his longitudinal study, Shankland, Genolini, Riou França, Guelfi, \& Ionescu (2010) specify that students from alternative schools, including Montessori, regulate better to higher education than their peers from traditional schools. Koh and Frick(2010) did a case study research that reviewed how supportive autonomy learning was applied in the upper Montessori plane. Student's autonomy in the Montessori philosophy directed teachers in applying an effective learning environment. It also helps teachers in integrating the idea of autonomy support in the teaching-learning process (Koh \& Frick, 2010). In relation to learners' autonomy, Mocanu (2012) studies methods in learning a foreign language that is seeing learners as a unique human being with feelings, emotions, and personal relationships. One of the methods developed by Caleb Gattegno was constructed by the Montessori principle of respecting learner autonomy.

Ireland, Watters, Brownlee, \&Lupton (2012) discover the inquiry-based learning use. It is one of the Montessori ideas in which teachers foster direct experiences that make their students learn in their way by drawing from their contributions. In their research, there is a focus change from the way teachers teach the way their students learn. The factor of students' strong social and cognitive outcomes indicated by Lillard (2013) is high-fidelity Montessori programs. Dahunsi (2014) examines the Montessori education in Nigeria, which is a developing country. The results show that the lack of learning materials becomes the problem in implementing the Montessori approach. Therefore, the Dahunsi (2014) suggests the government afford Montessori schools with the proper learning materials.

Moreover, Frierson (2016) argues that students in this era lack of autonomy. Frierson(Frierson, 2016) claims that it is because the students who seldom be put in a situation in which they can train their autonomy. On the other hand, the Montessori Method allows students to have accountability (Frierson, 2016). In India, Dhiksha and Suresh(2016)inspected how 60 students in Montessori and 64 students in non-Montessori programs contrasted in self-esteem and anxiety. The results show that Montessori students had higher self-esteem and lower academic anxiety compared to non-Montessori students. From the previous research, it can be inferred that it is fundamental to explore the Junior High School Montessori students' self-efficacy perceptions on their reading comprehension.

\section{METHOD}

The setting of this research was in a Montessori Junior High School in Yogyakarta, Indonesia. The participants were the eight Montessori students of the school in grade seven (three students) and grade eight (five students) enrolled in the academic year 2018-2019. In this setting, the students' age is between 12 to 14 years old. Three of them are female. They are all from Yogyakarta, Indonesia. Only one of the students' lives in the village while others live in the city. Most of them are from high-income families (13\% family's monthly income is between 2-5 million Rupiahs, 63\% is between 5-10 million Rupiahs, and $25 \%$ is above 10 million Rupiahs). According to the investigation of parents' educational level, $75 \%$ of fathers and $88 \%$ of mothers have a Bachelor's degree, two fathers have a Master's degree, and a mother has a Doctoral degree. $25 \%$ of the participants are single children, and the rest of them have one until two siblings. They read three books monthly on average, and the books they read are encyclopedia, fiction, history, novels, magazines, comics, and storybooks. $75 \%$ of them state that they have plenty of books in their homes. 
Firstly, the researchers asked the participants to fill the questionnaire voluntarily. Brown (2001) defines the questionnaire as a tool that has some questions or statements needed to be answered by the respondents. As cited in (Dörnyei, 2003), the questionnaire was about the students' self-efficacy perceptions of their reading comprehension. The researchers adapted the questionnaire from Yoğurtçu (Yoğurtçu, 2013) about the perceptions of reading comprehension efficacy. They are called the written and visual meaning, self-regulation in reading, high self-esteem in reading comprehension, and other general areas that are applicable in the setting. The researchers made a questionnaire containing twenty-seven closeended statements to be answered by the participants. They must give tick between strongly disagree $($ score $=1)$, disagree $($ score $=2)$, somehow agree $($ score $=3)$, agree $($ score $=4)$ and strongly agree $($ score $=5)$. The researchers used the Likert Scale to measure their perceptions. Likert (1932) describes the Likert scale as a basic instrument to quantify concepts in measuring the psychosocial phenomena. Warmbrod (2014) states the score for the Likert scale is to define the whole statements. The researchers multiplied the number of participants who chose each option to the score of each option. The researchers picked five statements that have the highest and the lowest score to explore their perceptions in detail. After the researchers analyzed the data from the close-ended questionnaire, they analyzed the results from the open-ended questions about their self-efficacy perceptions by describing.

The researchers made use of the mixed method. Creswell and Creswell (2018) define that mixed methods research combines quantitative and qualitative methods in research. Precisely, the researchers conducted a concurrent triangulation strategy. Creswell and Creswell (2018) define that this strategy uses separate quantitative and qualitative methods to take advantage of the methods. The data from the close-ended questions were analyzed in quantitative manners while the other was analyzed in qualitative ways by using descriptive analysis.

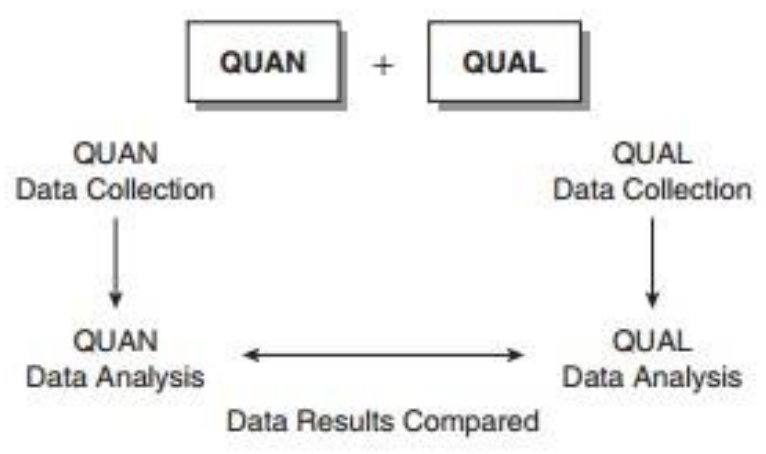

Figure 1. Concurrent Triangulation Strategy

\section{RESULT}

The students' reading comprehension self-efficacy perceptions are shown in Table 1. In general, the positive students' self-efficacy perceptions on their reading comprehension are higher $(46 \%)$ than their negative perceptions on it (17\%). The other $37 \%$ perceptions of the students somehow agreed with the statements. The percentage of the findings can be shown in the table below.

Table 1. Reading Comprehension Self-Efficacy Perceptions 


\begin{tabular}{|c|c|c|c|c|c|c|}
\hline \multirow{2}{*}{ No. } & \multirow{2}{*}{ Statement/score } & SD & $\mathbf{D}$ & So A & $\mathbf{A}$ & $\mathbf{S A}$ \\
\hline & & 1 & 2 & 3 & 4 & 5 \\
\hline 1 & $\begin{array}{l}\text { I can define the parts that I didn't understand } \\
\text { from the text. }\end{array}$ & $13 \%$ & $13 \%$ & $38 \%$ & $13 \%$ & $25 \%$ \\
\hline 2 & I can complete reading the whole book. & $0 \%$ & $0 \%$ & $13 \%$ & $25 \%$ & $63 \%$ \\
\hline 3 & I understand any text. & $0 \%$ & $0 \%$ & $100 \%$ & $0 \%$ & $0 \%$ \\
\hline 4 & $\begin{array}{l}\text { I can grasp the main topic of the reading text } \\
\text { in text related images }\end{array}$ & $0 \%$ & $0 \%$ & $38 \%$ & $50 \%$ & $13 \%$ \\
\hline 5 & I get high marks on reading comprehension. & $0 \%$ & $25 \%$ & $38 \%$ & $13 \%$ & $25 \%$ \\
\hline 6 & $\begin{array}{l}\text { I can read without the guidance of my } \\
\text { teachers. }\end{array}$ & $0 \%$ & $0 \%$ & $13 \%$ & $25 \%$ & $63 \%$ \\
\hline 7 & $\begin{array}{l}\text { I can determine the main and supporting ideas } \\
\text { of texts. }\end{array}$ & $0 \%$ & $0 \%$ & $50 \%$ & $38 \%$ & $13 \%$ \\
\hline 8 & I can explain and summarize after reading. & $0 \%$ & $0 \%$ & $13 \%$ & $63 \%$ & $25 \%$ \\
\hline 9 & I can make up my mind during the reading. & $0 \%$ & $0 \%$ & $38 \%$ & $50 \%$ & $13 \%$ \\
\hline 10 & $\begin{array}{l}\text { I can complete the reading, although the text } \\
\text { is boring. }\end{array}$ & $25 \%$ & $13 \%$ & $50 \%$ & $0 \%$ & $13 \%$ \\
\hline 11 & I can ask questions after reading. & $13 \%$ & $13 \%$ & $13 \%$ & $25 \%$ & $38 \%$ \\
\hline 12 & $\begin{array}{l}\text { I can make accurate predictions about the } \\
\text { texts I read. }\end{array}$ & $13 \%$ & $25 \%$ & $13 \%$ & $38 \%$ & $13 \%$ \\
\hline 13 & $\begin{array}{l}\text { I am one of the best in the classroom in terms } \\
\text { of reading comprehension. }\end{array}$ & $25 \%$ & $38 \%$ & $38 \%$ & $0 \%$ & $0 \%$ \\
\hline 14 & $\begin{array}{l}\text { I know what the author thinks when I am } \\
\text { reading. }\end{array}$ & $0 \%$ & $38 \%$ & $25 \%$ & $25 \%$ & $13 \%$ \\
\hline 15 & I easily catch the information about one topic. & $0 \%$ & $0 \%$ & $50 \%$ & $25 \%$ & $25 \%$ \\
\hline 16 & I have a long-term memory of what I read. & $0 \%$ & $13 \%$ & $50 \%$ & $0 \%$ & $38 \%$ \\
\hline 17 & I use my reading time wisely/efficiently. & $13 \%$ & $13 \%$ & $38 \%$ & $25 \%$ & $13 \%$ \\
\hline 18 & $\begin{array}{l}\text { I can define my thoughts clearly and } \\
\text { concisely after reading. }\end{array}$ & $0 \%$ & $0 \%$ & $50 \%$ & $25 \%$ & $25 \%$ \\
\hline 19 & I can summarize the text I read. & $0 \%$ & $13 \%$ & $38 \%$ & $38 \%$ & $13 \%$ \\
\hline 20 & I can evaluate the text I read. & $0 \%$ & $25 \%$ & $38 \%$ & $13 \%$ & $25 \%$ \\
\hline 21 & I can review the reading text clearly. & $0 \%$ & $25 \%$ & $13 \%$ & $38 \%$ & $25 \%$ \\
\hline 22 & I can take notes while I am reading. & $25 \%$ & $25 \%$ & $38 \%$ & $0 \%$ & $13 \%$ \\
\hline 23 & $\begin{array}{l}\text { I can grasp the meaning of text-related } \\
\text { images, tables, or graphics. }\end{array}$ & $0 \%$ & $0 \%$ & $25 \%$ & $50 \%$ & $25 \%$ \\
\hline 24 & I can easily understand the narrative texts. & $0 \%$ & $0 \%$ & $50 \%$ & $13 \%$ & $38 \%$ \\
\hline 25 & $\begin{array}{l}\text { I can have a second thought related to the } \\
\text { reading text. }\end{array}$ & $0 \%$ & $0 \%$ & $50 \%$ & $38 \%$ & $13 \%$ \\
\hline 26 & I feel good while I am reading. & $0 \%$ & $25 \%$ & $38 \%$ & $25 \%$ & $13 \%$ \\
\hline 27 & I don't get bored while I am reading. & $25 \%$ & $13 \%$ & $50 \%$ & $0 \%$ & $13 \%$ \\
\hline \multirow{2}{*}{\multicolumn{2}{|c|}{ Average }} & $6 \%$ & $12 \%$ & $37 \%$ & $24 \%$ & $22 \%$ \\
\hline & & \multicolumn{2}{|c|}{$18 \%$} & $37 \%$ & \multicolumn{2}{|c|}{$46 \%$} \\
\hline
\end{tabular}

Most of the students (88\%) have their highest level of positive perceptions on the statements number 2 (I can complete reading the whole book, A: 25\%, SA: 63\%), 6 (I can 
read without the guidance of my teachers, A: 25\%, SA: 63\%), and 8 (I can explain and summarize after reading, A: $63 \%$, SA: $25 \%$ ). Then, $75 \%$ of the students have a high level of positive perception (A: $50 \%$, SA: $25 \%$ ) on the statement number 23 (I can grasp the meaning of text-related images, table or graphics). It is supported by statement number 4 (A: $50 \%$, SA: 13\%), 9(A: 50\%, SA: 13\%), 11(A: 25\%, SA: 38\%), and 21(A: $38 \%$, SA: $25 \%$ ) on which more than $50 \%$ of the students $(63 \%)$ chose to agree and strongly agree. They are related to students' ability to use their mind in comprehending the figures, asking questions, and reviewing the reading texts.

On the other hand, there are $63 \%$ of the students. $38 \%$ of them chose to disagree, and $25 \%$ of them chose strongly disagree on question number 13 (I am one of the best in the classroom in terms of reading comprehension). $50 \%$ is on question number 22 , and $38 \%$ is on the questions number 10 and 27. They are about taking notes and boringness in reading.

To explore summated findings, the data from the close-ended questionnaire were processed to get the perception score. The researcher did it by multiplying the number of responses on each option to the score formulated (strongly disagree (score $=1$ ), disagree $($ score $=2)$, somehow agree (score $=3$ ), agree (4) and strongly agree (5)) and divided it by the number of participants (8) (see Table 2).

Table 2. Sorted Reading Comprehension Self-Efficacy Perceptions Score

\begin{tabular}{|c|l|l|}
\hline No. & \multicolumn{1}{|c|}{ Statement } & Perception Score \\
\hline 2 & I can complete reading the whole book. & 4.5 \\
\hline 6 & I can read without the guidance of my teachers. & 4.5 \\
\hline 8 & I can explain and summarize after reading. & 4.125 \\
\hline 23 & $\begin{array}{l}\text { I can grasp the meaning of text-related images, tables, or } \\
\text { graphics. }\end{array}$ & 4 \\
\hline 24 & I can easily understand the narrative texts. & 3.875 \\
\hline 4 & $\begin{array}{l}\text { I can grasp the main topic of the reading text in text related } \\
\text { images }\end{array}$ & 3.75 \\
\hline 9 & I can make up my mind during the reading. & 3.75 \\
\hline 15 & I easily catch the information about one topic. & 3.75 \\
\hline 18 & $\begin{array}{l}\text { I can define my thoughts clearly and concisely after } \\
\text { reading. }\end{array}$ & 3.75 \\
\hline 7 & I can determine the main and supporting ideas of texts. & 3.625 \\
\hline 11 & I can ask questions after reading. & 3.625 \\
\hline 16 & I have a long-term memory of what I read. & 3.625 \\
\hline 21 & I can review the reading text clearly. & 3.625 \\
\hline 25 & I can have a second thought related to the reading text. & 3.625 \\
\hline 19 & I can summarize the text I read. & 3.5 \\
\hline 5 & I get high marks on reading comprehension. & 3.375 \\
\hline 20 & I can evaluate the text I read. & 3.375 \\
\hline 1 & I can define the parts that I didn't understand from the text. & 3.25 \\
\hline 26 & I feel good while I am reading. & 3.25 \\
\hline 12 & I can make accurate predictions about the texts I read. & 3.125 \\
\hline 14 & I know what the author thinks when I am reading. & 3.125 \\
\hline 17 & I use my reading time wisely/efficiently. & 3.125 \\
\hline & & \\
\hline
\end{tabular}




\begin{tabular}{|c|l|l|}
\hline 3 & I understand any text. & 3 \\
\hline 10 & I can complete the reading, although the text is boring. & 2.625 \\
\hline 27 & I don't get bored while I am reading. & 2.625 \\
\hline 22 & I can take notes while I am reading. & 2.5 \\
\hline 13 & $\begin{array}{l}\text { I am one of the best in the classroom in terms of reading } \\
\text { comprehension. }\end{array}$ & 2.125 \\
\hline \multicolumn{2}{|c|}{ Average } & 3.449 \\
\hline
\end{tabular}

The average score is 3.449 , which is falls within a range of somehow agree. From the sorted table, the researchers paid attention to the ten statements which have the highest (five statements) and the lowest score (five statements). The statements which have a higher score are statements number 2, 6, 8, 23, and 24, while the lowest are statements number 3, 10, 27, 22 , and 13. The number of statements that have a positive score is higher (22 out of 26). Furthermore, the score of the statements which have positive responses is significantly stronger compared to the statements which have the lowest score. The findings are discussed below.

In this paragraph, the findings from the five statements which have the highest score are discussed. Statement 2 (I can complete reading the whole book) and statement 6 (I can read without the guidance of my teachers) reach the highest score (score $=4.5)$. It is showing that the students perceived that they are confident enough to complete reading a whole book without the guidance of the teacher. It is shown in statement 8 the participants perceived that they could explain, summarize the content of the reading (score $=4.125$ ). In statement 23, the participants perceived that they could comprehend the images, table, or graphics found in the text $($ score $=4)$. The participants also perceived positively that they could easily understand the story found in the narrative texts (score $=3.875$ ).

The statements which have the lowest score are discussed in this paragraph. Statement 13 is the statement that has the lowest score (score $=2.125$ ). The students perceived that they are not the best students who can comprehend the text. Statement 22 got a (2.5) score showing that they are not confident in taking notes while reading. The findings found in statements 10 and 27 show that they sometimes get bored and could not finish their reading (score $=2.625$ ). Statement 3 has a 3 -score showing that they somehow agree that they are not confident in mastering any reading.

The findings from the open-ended questionnaire are about whether they are confident in comprehending a text. Three of them (P1, P2, and P5) answered that they are confident in doing that ( $\mathrm{P}=$ participant $)$. Two of them ( $\mathrm{P} 7 \& \mathrm{P} 8)$ wrote that sometimes they are confident, and sometimes they are not. Three other students (P3, P4, and P6) stated that they are not confident enough in comprehending reading text.

The researchers also analyzed the data from the open-ended questions to explore the sources participants' perceptions of their self-efficacy in reading comprehension. There are mastery experiences, Vicarious Experiences, Verbal Persuasion, Emotional and Physiological States, and Imaginal Experiences. Moreover, the researchers also analyzed the findings with the perspective of Montessori Education.

Direct experiences are the main causes of self-efficacy (Bandura, 1997). The researchers found some students who perceived that their experiences cause their self-efficacy in reading comprehension (see Excerpt 1 and 2).

\section{Excerpt 1. Participant 2's answer related to his mastery experience in reading particular books}


Yes, [I am confident] because I can comprehend books [about] world war 2. They are about ... (mentioning some historical figures).

\section{Excerpt 2. Participant 5's answer related to her mastery experience in reading particular books}

I am confident because I get used to reading books both in English and in Indonesian. ... Sometimes, I read [conventional] books or e-books got from the internet about romance, drama, [and] daily life.

The students perceived that they are confident in comprehending reading text because of their own experience in reading. The participants studied in a Montessori Junior High School and had passed the upper Montessori plane. The researchers observed some students were reading some books provided in the school's library in the individual time of the school. The findings are supported by Frick (2010), who found that supportive autonomy learning was applied in the upper Montessori plane. Shankland, Genolini, França, Guelfi, and Ionescu (2010) found that students from alternative schools, including Montessori, regulate better to higher education than their peers from traditional schools. Their autonomy will help them explore more things and get more experience. The researchers found that mastery experiences help them in perceiving that they have high self-efficacy in comprehending reading text.

\section{Vicarious Experiences}

Vicarious experiences are people's experiences around us, which can increase our selfefficacy (Bandura, 1997). The researchers found that vicarious experiences are one of the sources of their participants' self-efficacy in reading comprehension (see Excerpt 3).

Excerpt 3. Participant 5's answer related to the impact of others' activities and verbal persuasion to her self-efficacy perceptions in comprehending reading texts

I am supported [to be confident in comprehending reading text] when the previous readers encourage me to read a reading text and say that the text is interesting.

Lillard (1996) states that group work and discussion are usually effectively done in the teaching-learning process in Montessori school. Participant 5 perceives that she had more self-efficacy when she discussed with the previous readers. The sharing of the reading experience of others can help her in achieving more self-efficacy.

\section{Verbal Persuasion}

Bandura (1997) states that people around us can persuade us to master certain actions or activities. Excerpt 4 shows that the participant's mother asked her to read books. This kind of persuasion can help them in increasing their self-efficacy.

Excerpt 4. Participant 5's answer related to the impact of verbal persuasion to her selfefficacy perceptions in comprehending reading texts

... My mother asks me to read some books. ...

This is one of the examples of verbal persuasion as one of the self-efficacy sources of someone. Excerpt 3 is also related to verbal persuasion. We can see that the communication between readers and the prospective reader (in this case, Participant 5) can increase her confidence. On the other hand, Participant 2 shares her bad experience related to the absence of verbal persuasion. 
Excerpt 5. Participant 2's answer related to the absence of verbal persuasion in decreasing his self-efficacy perceptions in comprehending reading texts

Mocked and embarrassed by friends. They argued that I am not capable of fully comprehend the text that I read.

He was upset when people around him underestimated him. This was also experienced by participant 5 (see Excerpt 5).

Excerpt 6. Participant 5's answer related to the absence of verbal persuasion in decreasing his self-efficacy perceptions in comprehending reading texts

When people say that I am not old enough to understand the reading text because I feel people underestimate my ability to understand the reading text.

It is analyzed that proper verbal persuasion is one of the sources of the students' reading comprehension self-efficacy. On the other hand, the negative verbal intervention will decrease students' motivation in their reading comprehension. The findings are supported by Mcnamara (2016), who states that encouraging students' natural desires to learn is one of the goals in Montessori education.

\section{Emotional and Physiological States}

Both positive and negative emotional and physiological states are factors in our selfefficacy (Bandura, 1997). The researchers found that some students were bored in comprehending reading texts.

Excerpt 7. Participant 6's answer related to his negative emotions, a physiological state that decreases his self-efficacy perceptions in comprehending reading texts

I do not like to read because, in my opinion, it is a boring thing [to do]. I am bored because I only see the text.

Participant 6 felt bored in reading. His negative emotional and physiological states decreased his self-efficacy perception in reading. Another factor in decreasing self-efficacy happened in participant 7. The student perceived that he had a limited vocabulary bank (see Excerpt 7 and $8)$.

Excerpt 7. Participant 7's answer related to his negative emotions, a physiological state that decreases his self-efficacy perceptions in comprehending reading texts

Sometimes. Usually, I cannot comprehend vocabulary that I do not know before. In that position, I am starting to distrust.

Excerpt 8. Participant 3's answer related to his negative imaginal experiences that decrease his self-efficacy perceptions in comprehending reading texts.

The number of pages, because if the number of pages is a lot, I always worry about it.

The findings are following the theory of Bandura (1997) about emotional and physiological states as one of the factors of self-efficacy. However, one of the self-efficacy's sources, imaginal experiences, is not found in the research.

\section{CONCLUSION}


In conclusion, the results show that the students have positive self-efficacy perceptions of their reading comprehension (Average $=3.449 / 5$ ). They have positive self-efficacy perceptions in reading, explaining, summarizing the texts without the guidance of their teachers. The students also had high self-efficacy perceptions on their ability to comprehend the graphics in the texts and in comprehending the story found in the narrative texts. However, students have their low perceptions of taking notes and dealing with the boringness of reading. The researchers also found that their self-efficacy sources are found in their mastery experiences, vicarious experiences, verbal persuasion, and emotional and psychological states.

\section{REFERENCES}

Ary, D., Jacobs, L. C., Razavieh, A., \& Ary, D. (2010). Introduction to research in education (8th ed). Belmont, CA: Wadsworth.

C.Dent-Read and P. Zukow Goldring. (2001). Is modeling knowing? [Review of the book Models of cognitive development]. American Journal of Psychology, 126-133.

Creswell, J. W., \& Creswell, J. D. (2018). Research design: qualitative, quantitative, and mixed methods approach (Fifth edition). Los Angeles: SAGE.

Dahunsi T.O. (2014). Montessori Education in Nigeria. IOSR Journal of Research \& Method in Education, 4(1), 57-60.

Dhiksha J and Suresh A. (2016). Self-esteem and academic anxiety of high school students with Montessori and traditional methods of education. Indian Journal of Health \& Wellbeing, 7(5), 543-545.

Dörnyei, Z. (2003). Questionnaires in second language research: construction, administration, and processing. Mahwah, N.J: Lawrence Erlbaum Associates.

Frierson, P. R. (2016). Making Room for Children's Autonomy: Maria Montessori's Case for Seeing Children's Incapacity for Autonomy as an External Failing: Making Room for Children's Autonomy. Journal of Philosophy of Education, 50(3), 332-350. https://doi.org/10.1111/1467-9752.12134

Ireland, J. E., Watters, J. J., Brownlee, J., \& Lupton, M. (2012). Elementary Teacher's Conceptions of Inquiry Teaching: Messages for Teacher Development. Journal of Science Teacher Education, 23(2), 159-175. https://doi.org/10.1007/s10972-011-92512

Ireson, J. (2008). Learners, learning, and educational activity. London; New York: Routledge.

Likert, R. (1972). The Likert technique for attitude measurement. Social Psychology: Experimentation, Theory, Research, Sahakian, WS (Ed.). Intext Educational Publishers, Scranton, USA., ISBN-13: 9780700223879, 101-119.

Lillard, A. S. (2005). Montessori: the science behind the genius (Updated ed). Oxford; New York: Oxford University Press.

Lillard, A. S. (2013). Playful learning and Montessori education. American Journal of Play, 5(2), 157-186.

Lillard, P. P. (1996). Montessori today: a comprehensive approach to education from birth to adulthood. New York: Schocken Books.

Ling Koh, J. H., \& Frick, T. W. (2010). Implementing Autonomy Support: Insights from a Montessori Classroom. International Journal of Education, 2(2). https://doi.org/10.5296/ije.v2i2.511

M. Mocanu. (2012). Humanistic Methods In Foreign Language Teaching. Euromonitor. 
Montessori FAQ’s (Frequently Asked Questions). (n.d.). Retrieved December 23, 2019, from http://montessori.edu/FAQMontessori.html.

Montessori, M. (2014). The Montessori method. New Brunswick (U.S.A.): Transaction Publishers.

Montessori, M., \& Gutek, G. L. (2004). The Montessori method: the origins of educational innovation, including an abridged and annotated edition of Maria Montessori's The Montessori method. Lanham, Md: Rowman \& Littlefield Publishers.

Montessori, M., \& Lane, H. R. (2004). Education and peace. Oxford: Clio Press.

Montessori National Curriculum | Montessori Australia. (n.d.). Retrieved December 23, 2019, from https://montessori.org.au/montessori-national-curriculum.

Pintrich, P. R. (2003). A Motivational Science Perspective on the Role of Student Motivation in Learning and Teaching Contexts. Journal of Educational Psychology, 95(4), 667686. https://doi.org/10.1037/0022-0663.95.4.667.

Priestley, M., \& Biesta, G. (Eds.). (2013). Reinventing the curriculum: new trends in curriculum policy and practice. London: Bloomsbury Pub.

Priestley, M., Edwards, R., Priestley, A., \& Miller, K. (2012). Teacher Agency in Curriculum Making: Agents of Change and Spaces for Manoeuvre. Curriculum Inquiry. https://doi.org/10.1111/j.1467-873X.2012.00588.X.

Shankland, R., Genolini, C., Riou França, L., Guelfi, J.-D., \& Ionescu, S. (2010). Student adjustment to higher education: the role of alternative educational pathways in coping with the demands of student life. Higher Education, 59(3), 353-366. https://doi.org/10.1007/s10734-009-9252-7.

Sorrel Brown. (2010). Likert scale examples for surveys. ANR Program Evaluation. Iowa State University Extension.

Tinka Ivanova. (2014). The Place Of The Teacher In The System Of Pedagogy Of Maria Montessori And The Contemporary System Of Education. Management \& Education / Upravlenie I Obrazovanie, 10(3), 26-32.

Warmbrod, J. R. (2014). Reporting and Interpreting Scores Derived from Likert-type Scales. $\begin{array}{llll}\text { Journal of Agricultural 30-47. } & \text { Education, }\end{array}$ https://doi.org/10.5032/jae.2014.05030

Yoğurtçu, K. (2013). The Impact of Self-efficacy Perception on Reading Comprehension on Academic Achievement. Procedia - Social and Behavioral Sciences, 70, 375-386. https://doi.org/10.1016/j.sbspro.2013.01.075. 